\title{
ENERGY USE IN APPLE PRODUCTION IN THE ESFAHAN PROVINCE OF IRAN
}

\author{
M. SAMI, M.J. SHIEKHDAVOODI ${ }^{1}$ and A. ASAKEREH ${ }^{2}$ \\ Department of Agricultural Machinery Engineering, Shahid Chamran University of Ahvaz, Iran \\ ${ }^{1}$ Department of Agricultural Machinery Engineering, Shahid Chamran University of Ahvaz, Iran \\ ${ }^{2}$ Department of Agricultural Machinery Engineering, Faculty of Agricultural Engineering and Technology, \\ University of Tehran, Karaj, Iran \\ Corresponding author: Asakereh@ut.ac.ir
}

(Received 8 October, 2010; accepted 26 March, 2011)

\begin{abstract}
Energy is a fundamental ingredient in the process of economic development, as it provides essential services that maintain economic activity and the quality of human life. Modern agriculture has become very energy-intensive. The aim of this study was to evaluate energy use in apple production in the Esfahan Province in Iran. Data used in this study were obtained from 146 farmers using a face to face interview method. The total energy requirement under apple farming was $36,135.16 \mathrm{MJ} \mathrm{ha}^{-1}$, whereas $46.2,25$ and $15.8 \%$ was consumed due to chemicals, fuel and manure fertiliser, respectively. Renewable energy was $23.6 \%$ of total energy input. The input-output ratio, productivities, specific and net energy gain were $1.17,0.49 \mathrm{~kg} \mathrm{MJ}^{-1}, 2.05 \mathrm{MJ} \mathrm{kg}^{-1}$ and 6,143.2 $\mathrm{MJ} \mathrm{ha}^{-1}$, respectively. Apple production needs to improve the efficiency of energy consumption and to employ renewable energy.
\end{abstract}

Key Words: Energy intensive, energy ratio, renewable energy

\section{RÉSUMÉ}

L'énergie est un ingrédient fondamental dans le processus de développement économique, étant donné qu'elle fournit de services essentiels pour le maintien des activités économiques et la qualité de vie humaine. L'agriculture moderne est devenue trop exigente en énergie. L'objet de cette étude était d'évaluer l'usage de l'énergie dans la production de la pomme dans la Province d' Esfahan en Iran. Les données utilisées dans cette étude étaient obtenues de 146 fermiers par la méthode d'interview face à face. Le total des besoins en énergie pour la production de la pomme était de 36,135.16 $\mathrm{MJ} \mathrm{ha}^{-1}$, alors que 46.2, 25 et 15.8\% étaient consommés par des produits chimiques, le carburant et la fumure organique, respectivement. L'énergie renouvelable était de $23.6 \%$ du total d'énergie fournie. Le rapport de l'énergie fournie à celle consommée, la productivité, le gain net et spécifique en énergie étaient de 1.17, $0.49 \mathrm{~kg} \mathrm{MJ}^{-1}, 2.05 \mathrm{MJ} \mathrm{kg}^{-1}$ et 6,143.2 $\mathrm{MJ} \mathrm{ha}^{-1}$, respectivement. La production de la pomme nécessite une amelioration efficiente de la consommation énergétique et l'emploi de l'énergie renouvelable.

Mots Clés: Energie intensive, rapport énergétique, énergie renouvelable

\section{INTRODUCTION}

Energy use in agriculture has developed in response to increasing populations, limited supply of arable land and desire for an increasing standard of living. In all societies, these factors have encouraged an increase in energy inputs to maximise yields, minimise labour-intensive practices or both (Esengun et al., 2007). The agriculture sector, like other sectors, has become increasingly dependent on energy resources such as electricity, fuels, natural gas and coke. Continuous demand for increase in food production has resulted in intensive use of chemical fertilisers, pesticides, agricultural machinery and other natural resources. 
However, intensive use of energy threatens public health and environment (Dalgaard et al., 2001) and is partly responsible for the deterioration of world peace and development (Demirbas, 2006; Grennan, 2006).

This increase in energy use and its associated increase in capital intensive technology, can be partially attributed to low-energy prices in relation to the resource for which it was being substituted (Karkacier et al., 2006). Energy is a fundamental ingredient in the process of economic development, as it provides essential services that maintain economic activity and the quality of human life. Shortages of energy are a serious constraint to the development of lowincome countries. However, considering the limited natural resources and the impact of using different energy sources on environment and human health, it is imperative to investigate energy use patterns in agriculture (Hatirli et al., 2005). Energy input-output analysis is usually used to evaluate the efficiency and environmental impacts of production systems (Uhlin, 1998; Yilmaz et al., 2005).

Apples are one of the most common fruits consumed on a regular basis by people globally. Apples in most countries are crops with highenergy inputs, due to inputs in machinery, chemicals and human labour) required for successful commercial production of highquality fruit (Strapatsa et al., 2006). Apples in Iran are often produced in mountainous and cold areas.

Iran produces 2.66 million metric tonnes of apples in each year (Anon., 2009). Most of them are exported to neighbouring countries such as the United Arab Emirates, Turkey and Germany (Tabatabaeefar and Rajabipour, 2005).

The aim of this study was to assess energy use in apple production, and the efficiency of energy consumption.

\section{MATERIALS AND METHODS}

The study was carried out in 146 apple producers in the Esfahan province in Iran. The province is located in the centre of Iran, within $30^{\circ} 43^{\prime}$ and $34^{\circ} 27^{\prime} \mathrm{N}$ latitude and $49^{\circ} 36^{\prime}$ and $55^{\circ} 31^{\prime} \mathrm{E}$ longitude. Data were collected from the growers by using a face-to-face questionnaire in March to April 2009. Random sampling of farms was done within whole population and the size of each sample was determined using Equation (1) derived from Neyman method (Ozkan et al., 2004).

$\mathrm{n}=1\left(\sum \mathrm{N}_{\mathrm{h}} \mathrm{S}_{\mathrm{h}}\right) /\left(\mathrm{N}^{2} \mathrm{D}^{2}+\sum \mathrm{N}_{\mathrm{h}} \mathrm{S}_{\mathrm{h}}^{2}\right)$

Where:

n - Required sample size;

$\mathrm{N}$ - Number of holdings in target population;

$N_{h}$ - Number of the population in the hr stratification;

$S_{h}$ - Standard deviation in the h stratification;

$S_{h}^{2}$ - Variance of h stratification;

$\mathrm{d}$ - Precision where $(\overline{\mathrm{X}}-\overline{\mathrm{X}})$; and

z - Reliability coefficient (1.96, which represents the $95 \%$ reliability); $\mathrm{D}^{2}=\mathrm{d}^{2} / \mathrm{z}^{2}$.

Inputs in apple production in Iran are human labour, machinery, diesel fuel, inorganic fertilisers, manure, pesticides and irrigation water (Rafiee et al., 2010). Outputs are apple fruits. Energy equivalents shown in Table 1 were used for estimation. Basic information on energy inputs and apple yields were analysed using the SPSS Version 16.

Based on the energy equivalents of the inputs and outputs, output-input energy ratio, energy productivity, specific energy and net energy gain were calculated (Singh, 2002; Sartori et al., 2005; Demircan et al., 2006).

The input energy is also classified into direct and indirect; and renewable and non-renewable forms. The indirect energy consists of pesticide, fertiliser, machine and equipment; while the direct energy includes human power and diesel used in the production process. On the other hand, non-renewable energy includes diesel, electricity, pesticide, fertilisers; while renewable energy consists of human and manure fertiliser (Demircan et al., 2006). 
TABLE 1. Energy equivalents for different inputs and outputs in apple production in Iran

\begin{tabular}{llcl}
\hline Input & Unit & Energy equivalent (MJ unit $\left.{ }^{-1}\right)$ & Reference/Source \\
\hline Labour & $\mathrm{h}$ & 2.2 & Pimentel and Pimentel., 1979 \\
Machinery & $\mathrm{hg}$ & 138 & Kitani, 1999 \\
Diesel fuel & $\mathrm{L}$ & 56.31 & Singh, 2002 \\
Gasoline & $\mathrm{L}$ & 46.3 & Kitani, 1999 \\
Manure & ton & 303.1 & Esengun et al., 2007 \\
Nitrogen fertiliser & $\mathrm{kg}$ & 74.2 & Lockeretz, 1980 \\
Phosphorus fertiliser $\left(\mathrm{P}_{2} \mathrm{O}_{5}\right)$ & $\mathrm{kg}$ & 13.7 & Lockeretz, 1980 \\
Potassium fertiliser $\left(\mathrm{K}_{2} \mathrm{O}\right)$ & $\mathrm{kg}$ & 9.7 & Lockeretz, 1980 \\
Ca and Mg fertiliser & $\mathrm{kg}$ & 8.8 & Pimentel and Pimentel, 1979 \\
Pesticide & $\mathrm{kg}$ & 363 & Fluck and Baird, 1982 \\
Fungicide & $\mathrm{kg}$ & 99 & Fluck and Baird, 1982 \\
Herbicide & $\mathrm{kg}$ & 288 & Kitani, 1999 \\
Apple & $\mathrm{kg}$ & 2.4 & Jarach, 1985 \\
\hline
\end{tabular}

\section{RESULTS AND DISCUSSION}

Socio-economic structure of apple farms. The farms investigated were mainly devoted to apple production. Most farms were irrigated using the flow method; while the rest use pumping irrigation (Table 2). Tillage was done based on type, mechanised or non-mechanised. In the non-mechanised form, tillage was done with human power while in the mechanised form was done with rotary tiller that gives power from power take off shaft of tractor. Scatter of manure was done before tillage operation. The spread of manure was done with human power and cart or with tractor and human power.

Operations of pest control mainly were mechanised and a few of them (e.g. fungicide) were non-mechanised. Pruning operations were done with labour power and handsaw or motor saw. Harvesting was done by labour. Inorganic fertiliser were used a bit (about $8 \mathrm{~kg} \mathrm{ha}^{-1}$ ) while manure consumed a lot $\left(18,836 \mathrm{~kg} \mathrm{ha}^{-1}\right)$. Because, a lot of manure was in the region, use of manure was substantial. Application of inorganic fertilisation was manual while manure application was done by fertilising equipment and labour. Of all inorganic fertilisers, the share of nitrogen phosphorus $\left(\mathrm{P}_{2} \mathrm{O}_{5}\right)$, potassium $\left(\mathrm{K}_{2} \mathrm{O}\right)$, and $\mathrm{Mg}$ plus $\mathrm{Ca}$ were $33.5,8.8,35.9$, $21.8 \%$, respectively.

Analysis of energy use. The energy inputs for each operation in apple production are illustrated
TABLE 2. Energy inputs for each operation for apple production in Iran

\begin{tabular}{lcr}
\hline Operations & $\begin{array}{c}\text { Sequestered } \\
\text { energy (MJ ha-1) }\end{array}$ & \multicolumn{1}{c}{$\%$} \\
\hline Spring tillage & 2052.48 & 5.68 \\
Pruning & 661.27 & 1.83 \\
Practice of manure & 7808.81 & 21.61 \\
Inorganic fertilisation & 701.02 & 1.94 \\
Pest control & 22252.03 & 61.58 \\
Weed control & 130.08 & 0.36 \\
Supply water for irrigation & 1261.11 & 3.49 \\
Irrigation (control an scatter ) & 393.87 & 1.09 \\
Harvest & 870.86 & 2.42 \\
& & \\
Total & 36135.16 & 100 \\
\hline
\end{tabular}

in Table 3. Pest control was the most energyconsuming operation and was the premier of energy inputs required in apple production farms. These results are similar to those of Canals et al. (2006) and Stapatsa et al. (2006) in apple orchard in New Zealand and Greece respectively. However in many studies in orchards, inorganic fertilisers were also the most energy consumer in production (Gezer et al., 2003; Esengun et al., 2007; Canakci, 2010).

Chemicals consume $46.2 \%$ of total energy inputs due to high energy sequestered in operation of pest control, which was practiced extensively. After chemical, fuel and manure are the most energy consumer inputs, contributing 25 and $15.80 \%$ of total energy use, respectively 
(Table 3). Fuel (mostly diesel fuel) was mainly consumed for land preparation, pruning practices and transportation.

Inorganic fertiliser was the least demanding energy input in apple production with 325.22 $\mathrm{MJ} \mathrm{ha}^{-1}$ (only $0.44 \%$ of the total input energy) (Table 3) followed by machinery with 542.03 $\mathrm{MJ} \mathrm{ha}^{-1}$ (1.5\% of the total input energy). These results are significantly differed from the result of other studies where inorganic fertilisers consumption was high (Canals et al., 2006; Stapatsa et al., 2006; Page, 2009). In the studied orchard inorganic fertilisers was usually replaced by manure that is a strong point from energy and environment point of view.

Because orchards are usually watered with surface water, which should mean lower energy consumption than pumping groundwater, energy of irrigation was low (Tables 3 and 4).

A total of $76.4 \%$ of total energy input resulted from non-renewable and $23.6 \%$ from renewable energy; also $32.8 \%$ from direct energy and $67.2 \%$ indirect energy (Table 5).

TABLE 3. Distribution of sequestered energy to inputs in apple production in Iran

\begin{tabular}{lrr}
\hline $\begin{array}{l}\text { Sequestered } \\
\text { energy (MJha }{ }^{-1} \text { ) }\end{array}$ & $\begin{array}{c}\text { Coefficient of } \\
\text { production }\end{array}$ & $\%$ \\
\hline Labour & 2818.54 & 7.8 \\
Machinery & 542.03 & 1.5 \\
Fuel & 9033.79 & 25.0 \\
Chemicals & 16694.44 & 46.2 \\
Chemical fertiliser & 325.22 & 0.9 \\
Manure & 5709.36 & 15.8 \\
Irrigation & 1011.78 & 2.8 \\
& & \\
Total & 36135.16 & 100 \\
\hline
\end{tabular}

TABLE 4. Total energy input in the form of direct, direct renewable, non-renewable and indirect energy for apple production in Iran

\begin{tabular}{lrc}
\hline Item & MJ ha $^{-1}$ & $\%$ \\
\hline Direct energy & 11852.33 & 32.8 \\
Indirect energy & 24282.83 & 67.2 \\
Nonrenewable energy & 27607.26 & 76.4 \\
Renewable energy & 8527.9 & 23.6 \\
\hline
\end{tabular}

TABLE 5. Energetic parameters in apple production in Iran

\begin{tabular}{llr}
\hline Energy input & $\mathrm{MJ} \mathrm{ha}^{-1}$ & 36135.2 \\
Energy output & $\mathrm{MJ} \mathrm{ha}^{-1}$ & 42278.4 \\
Yield & $\mathrm{kg} \mathrm{ha}^{-1}$ & 17616 \\
Input-output energy ratio & - & 1.17 \\
Energy productivity & $\mathrm{kg} \mathrm{MJ}^{-1}$ & 0.49 \\
Specific energy & $\mathrm{MJ} \mathrm{kg}^{-1}$ & 2.05 \\
Net energy gain & $\mathrm{MJ} \mathrm{ha}^{-1}$ & 6143.2 \\
\hline
\end{tabular}

Direct inputs were mainly fuel and labour for field operations; and the indirect inputs were dominated by chemicals and manure. In other words, apple production was highly dependent on both fuel and the production of indirect inputs. Proper chemicals and manure management might reduce the indirect energy requirements for pest control and manure. Furthermore, efforts to reduce the direct energy (fuel and labour), will improve overall energy efficiency of apple production in agricultural production systems. The results indicate that the current energy use pattern among farms is mainly based on non-renewable (Table 5).

Average yield of the apple fruit was found to be $17,616 \mathrm{~kg} \mathrm{ha}^{-1}$. This amount is higher than average yield in the world $\left(14.36 \mathrm{t} \mathrm{ha}^{-1}\right)$ in 2008 . In energy balances, the output-input energy ratio is often used as a parameter to describe the energy efficiency in agricultural production. The average output-input energy ratio was 1.17 . In studies that were done on apple production systems, energy ratio was mostly reported between 1 to 2 (such as 1.57 reported by Page, 2009, 1.18 reported by Pimentel et al., 1983 and $1.11,1.13$ and 1.118 reported by Reganold et al., 2001). Other previous studies reported energy ratio indices of 0.06 (Pimentel et al., 1983), 0.61 (Pimentel, 2006) and 2.34 (Strapatsa et al., 2006). Energy productivity, specific energy and net gain energy were respectively obtained as $0.49,2.05$ and 6,143.2 $\mathrm{MJ} \mathrm{ha}^{-1}$, for the study.

\section{CONCLUSION}

Total input energy in apple production in Esfahan Province of Iran is 36,135.16 $\mathrm{M} \mathrm{J} \mathrm{ha}^{-1}$. Chemicals for pest control, fuel for operation and manure are the major energy inputs with 46.2 , 25 , and $15.8 \%$, respectively. About seventy four 
percent of total energy input in apple production is non-renewable, while $23.6 \%$ is renewable. Also $32.8 \%$ of total input energy is direct and the rest is indirect. Thus, use of renewable energy in the studied farms is low. It shows that apple needs to improve the efficiency of energy consumption in production and to employ renewable energy.

\section{REFERENCES}

Anonymous. 2009. Statistical Yearbook of Agriculture. Statistic of agronomy. Statistical and information technology office. Ministry of Jihad-e-Agriculture Publication, Iran.

Awad, M.A., Wagenmakers, P.S. and De Jager, A. 2001. Effects of light on flavonoid and chlorogenic acid levels in the skin of Jonagold apples. Scientia Horticulture 88:289-298.

Canakci, M. 2010. Energy use pattern and economic analyses of pomegranate cultivation in Turkey. African Journal of Agricultural Research 5(7): 491-499.

Canals, L.M., Burnip, G.M. and Cowell, S.J. 2006. Evaluation of the environmental impacts of apple production using Life Cycle Assessment (LCA): Case study in New Zealand. Agriculture, Ecosystems and Environment 114:226-238.

Dalgaard, T., Halberg, N. and Porter, J.R. 2001. A model for fossil energy use in Danish agriculture used to compare organic and conventional farming. Agriculture, Ecosystem and Environment 1: 51-65.

Demirbas, A. 2006. Progress and recent trends in biofuels. Progress in Energy and Combustion Science 32:389-98.

Demircan, V., Ekinci, K.H., Keener, M., Akbolat, D. and Ekinci, C. 2006. Energy and economic analysis of sweet cherry production in Turkey: A case study from Isparta province. Energy Conversion Management 47:1761-1769.

Esengun, K., Gunduz, O. and Erdal, G. 2007. Input-output energy analysis in dry apricot production of Turkey. Energy Conversion and Management 48:592-598.
Fluck, R.C. and Baird, C.D. 1982. Agricultural Energetics. Westport, CT, AVI Publications. Gowdy, J.M., Miller, J.L. and Kherbachi, H. 1987. Energy use in US agriculture. Southern Journal of Agricultural Economics 2:33-41.

Gezer, I., Acaroglu, M. and Haciseferogullari, H. 2003. Use of energy and labour in apricot agriculture in Turkey. Biomass Bioenergy 24(3):215-9.

Grennan, A.K. 2006. Regulation of starch metabolism in Arabidopsis leaves. Plant Physiology 142:1343-1345.

Hatirli, S.A., Ozkanb, B. and Fert, C. 2005. An econometric analysis of energy input-output in Turkish agriculture. Renewable and Sustainable Energy Reviews 9:608-623.

Jarach, M. 1985. Sui valori di equivalenza per l' analysi e il bilancioenergetici in agricoltura. Riv. Ingegneria Agraria 2:102-114.

Karkacier, O., Goktolga, Z.G. and Cicek, A. 2006. A regression analysis of the effect of energy use in agriculture. Energy Policy 34:37963800 .

Kitani, O. 1999. CIGR Handbook of Agricultural Engineering, Volume V: Energy and Biomass Engineering. ASAE publication, USA, St. Joseph, MI, USA. pp. 17-20.

Lockeretz, W. 1980. Energy inputs for nitrogen, phosphorus and potash fertilisers, In: Pimentel, D. (Ed.).Handbook of Energy Utilisation in Agriculture. Boca Raton, FL, CRC.

Ozkan, B., Akcaoz, H. and Karadeniz, F. 2004. Energy requirement and economic analysis of citrus production in Turkey. Energy Conversion Management 45: 1821-1830.

Page, G. 2009. An environmentally-based systems approach to sustainability analyses of organic fruit production systems in New Zealand. PhD Dissertation. Massey University, Palmerston North, New Zealand.

Pimentel, D. 2006. Impacts of organic farming on the efficiency of energy use in agriculture. An organic center state of science review. Awalible from http:// www.organic-center.org/reportfiles/ ENERGY_SSR.pdf. 
Pimentel, D. and Pimentel, M. 1979. Food, Singh, J.M. 2002. Onfarm energy use patterm Energy and Society. Edward Anold, London, in different cropping systems in Haryana, UK.

Pimentel, D., Berardi, G. and Fast, S. 1983. Energy efficiency of farming systems; organic and conventional agriculture. Agriculture, Ecosystem and Environment 9:359-372.

Rafiee, S., Mousavi Avval, S.H. and Mohammadi, A. 2010. Modeling and sensitivity analysis of energy inputs for apple production in Iran. Energy 35:3301-3306.

Reganold, J.P., Glover, J.D., Andrews, P.K. and Hinman, H.R. 2001. Sustainability of three apple production systems. Nature 410:926930.

Sartori, L., Basso, B., Bertocco, M. and Oliviero, G. 2005. Energy use and economic evaluation of a three year crop rotation for conservation and organic farming in NE Italy. Biosystems Engineering 9(2):245-250. India. Master of Science thesis. Management University of Flensburg, Germany.

Strapatsa, A.V., Nanos, G.D. and Tsatsarelis, C.A. 2006. Energy flow for integrated apple production in Greece. Agriculture, Ecosystems and Environment 116:176180.

Tabatabaeefar, A. and Rajabipour, A. 2005. Modeling the mass of apples by geometrical attributes. Scientia Horticulture 105: 373382.

Uhlin, H. 1998. Why energy productivity is increasing: An I-O analysis of Swedish agriculture. Agriculture System 56(4):443465.

Yilmaz, L., Akaoz, H. and Ozkan, B. 2005. An analysis of energy use and input costs for cotton production in Turkey. Renewable Policy 34:3796 - 3800. 